\title{
ETHANOL CONCENTRATION OF TRADITIONAL ALCOHOLIC BEVERAGES IN NORTHERN TANZANIA
}

\section{Authors:}

Joel M Francis, MD, PhD. ${ }^{1}$, Heiner Grosskurth, MD, PhD. ${ }^{1,2,3}$, Saidi H Kapiga, MD, DSc. ${ }^{1,2,3}$, Helen A Weiss, PhD. ${ }^{2}$, Joseph Mwashiuya, BSc, MSc. ${ }^{4}$, John Changalucha, BSc, MSc. ${ }^{1}$

${ }^{1}$ Mwanza Centre, National Institute for Medical Research, Mwanza, Tanzania

${ }^{2}$ MRC Tropical Epidemiology Group, Department of Infectious Disease Epidemiology, London School of Hygiene and Tropical Medicine, London, UK

${ }^{3}$ Mwanza Intervention Trials Unit (MITU), Mwanza, Tanzania

${ }^{4}$ Tanzania Food and Drug Authority (TFDA), Dar es Salaam, Tanzania

${ }^{\S}$ Corresponding author’s address:

National Institute for Medical Research, Mwanza Centre, P.O.Box 1462, Mwanza, Tanzania.

E-mail:

joelmfrancis@gmail.com

joelmf@hsph.harvard .edu

Telephone number +255784525294 .

The study was funded through the STRIVE Consortium, using funds from the Department of International Development (DFID) of the United Kingdom. 
In sub-Saharan Africa (SSA), the annual consumption of pure alcohol has been estimated to range from 4.9-7.1L per capita, although intake is likely to be significantly higher because of the unrecorded consumption of traditionally produced beverages (World Health Organisation, 2014). These account for an estimated $30 \%$ of pure alcohol consumption. In Tanzania, the per capita consumption of industrially produced alcoholic drinks is equivalent to about $5 \mathrm{~L}$ of pure alcohol and the additional annual per capita amount of unrecorded consumption of locally brewed alcohol has been estimated at about 2L of pure alcohol (World Health Organisation, 2014).

Few studies from SSA have investigated the alcohol concentration of typical traditional brews (Mavioga et al., 2009; Nikander et al., 1991; Papas et al., 2010; Tusekwa et al., 2000) leading to substantial uncertainty of the estimated per capita consumption of unrecorded locally brewed alcohol. We are aware of only two studies from Tanzania that have estimated the level of alcohol in traditional alcoholic drinks (Nikander, et al., 1991; Tusekwa, et al., 2000). No study has been conducted in northern Tanzania. Our research aimed to close this information gap by assessing samples of popular locally produced beverages in Mwanza city in Northern Tanzania.

Mwanza is the second largest city in Tanzania (after the capital city of Dar es Salaam) and has a population of about 800,000 inhabitants (Tanzania National Bureau of Statistics, 2013). We identified local traditional brew outlets through a mapping exercise. We recorded local names and materials used for production of the available beverages. The investigator purchased samples of each available beverage from seven randomly selected outlets in three urban wards of Mwanza city, Tanzania. Samples were analyzed according to an internationally standardised method for the determination of ethanol concentration (Tanzania Bureau of Standards, 1992). 
We found that the traditional beers had ethanol concentrations ranging from $2-8 \% \mathrm{v} / \mathrm{v}$. Most had concentrations of above $4 \% \mathrm{v} / \mathrm{v}$ and the local spirits had the highest concentration, up to $55 \% \mathrm{v} / \mathrm{v}$ (Table 1). Concentrations varied widely, even for the same type of drink. Our findings were similar to those reported by the few other studies on traditional brews from other parts of Tanzania (Nikander, et al., 1991; Tusekwa, et al., 2000), and other parts of sub-Saharan Africa (Mavioga, et al., 2009; Papas, et al., 2010; Saungweme et al., 1999).

Our study had some limitations. We focused on ethanol content and did not conduct an analysis of other ingredients that can be found in traditional beverages and that may present a major health risk in their own right. Such ingredients may include toxic substances such as methanol, aflatoxin or high concentrations of ionised iron (Nikander, et al., 1991; Saungweme, et al., 1999). Alcohol concentrations found in our study may have been slightly overestimated as we cannot exclude that some further fermentation occurred after sample collection. However, our samples were stored in cold boxes at about $-8^{\circ} \mathrm{C}$ just after collection and at $-20^{\circ} \mathrm{C}$ soon thereafter in order to reduce or eliminate further fermentation.

We conclude that at the individual level, our findings facilitate the translation of the reported consumption of traditional beverages into estimates of the actual amount of pure alcohol taken, thus providing a prerequisite for patient care and group interventions aiming to reduce alcohol consumption and alcohol use disorders. (Word count 539)

\section{Competing Interest}

The authors do not report any conflict of interest. 


\section{Acknowledgement}

The study was funded through the STRIVE Consortium, using funds from the Department of International Development (DFID) of the United Kingdom. We thank the health and administrative authorities of Mwanza city for the permission to conduct the research. We are grateful to the vendors for their constructive participation and for providing detailed information on the beverages sold. 
Table 1. General characteristics and alcohol concentration of the alcohol beverages available in northern Tanzania

\begin{tabular}{|c|c|c|c|c|c|c|c|}
\hline $\begin{array}{c}\text { Local name of } \\
\text { beverage }\end{array}$ & Type & Shelf life & Ingredients & $\begin{array}{c}\text { Number of } \\
\text { samples } \\
\text { investigated }\end{array}$ & $\begin{array}{c}\text { Mean } \\
\text { Ethanol[SD } \\
\text { ](\% v/v }))\end{array}$ & $\begin{array}{l}\text { Ethanol (\%v/v) } \\
\text { (Min, Max) }\end{array}$ & $\begin{array}{l}\text { Coefficient of } \\
\text { variation (\%) }\end{array}$ \\
\hline Gongo(type 1) & Spirit & $\begin{array}{l}6-12 \\
\text { months }\end{array}$ & $\begin{array}{l}\text { Fermented (cassava and } \\
\text { germinating maize) }\end{array}$ & 5 & $53.3[3.1]$ & {$[47.9,55.4]$} & 5.8 \\
\hline Gongo ( type 2) & Spirit & $\begin{array}{l}\text { 6-12 } \\
\text { months }\end{array}$ & $\begin{array}{l}\text { Fermented (cassava and } \\
\text { germinating maize) }\end{array}$ & 7 & $22.7[3.5]$ & {$[15.1,26.3]$} & 15.6 \\
\hline Kangara & Beer & 2-3 days & husk of corn, maize, sorghum & 3 & $6.1[1.8]$ & {$[4.9,6.7]$} & 16.7 \\
\hline Waini & Beer & 1 week & sugar, black tea leaves, yeast & 6 & $6.0[2.3]$ & {$[5.3,7.6]$} & 15.5 \\
\hline Komoni & Beer & 24 hours & husk of corn, maize, sorghum & 9 & $5.4[1.6]$ & {$[4.6,6.2]$} & 8.5 \\
\hline Kindi & Beer & 24 hours & maize, sorghum & 3 & $4.2[0.7]$ & {$[4.0,4.7]$} & 9.5 \\
\hline Mbege & Beer & 24 hours & banana juice and sorghum & 3 & $2.2[0.9]$ & {$[1.6,2.5]$} & 23.6 \\
\hline
\end{tabular}




\section{REFERENCES}

Mavioga, E. M., Mullot, J. U., Frederic, C., Huart, B., \& Burnat, P. (2009). Sweet little Gabonese palm wine: a neglected alcohol. West Afr J Med, 28, 291-294.

Nikander, P., Seppala, T., Kilonzo, G. P., Huttunen, P., Saarinen, L., Kilima, E., \& Pitkanen, T. (1991). Ingredients and contaminants of traditional alcoholic beverages in Tanzania. Trans R Soc Trop Med Hyg, 85, 133-135.

Papas, R. K., Sidle, J. E., Wamalwa, E. S., Okumu, T. O., Bryant, K. L., Goulet, J. L., . . . Justice, A. C. (2010). Estimating alcohol content of traditional brew in Western Kenya using culturally relevant methods: the case for cost over volume. AIDS Behav, 14, 836844. doi: 10.1007/s10461-008-9492-Z

Saungweme, T., Khumalo, H., Mvundura, E., Moyo, V. M., Gordeuk, V. R., Rouault, T. A., .. . Gangaidzo, I. T. (1999). Iron and alcohol content of traditional beers in rural Zimbabwe. Cent Afr J Med, 45, 136-140.

Tanzania Bureau of Standards. (1992). Methods of sampling and test for alcoholic beverages. TBS printing, Dar es Salaam, Tanzania.

Tanzania National Bureau of Statistics. (2013). Tanzania Household Population Census (PHC) 2012 Tanzania Household Population Census (PHC). Dar es Salaam, Tanzania.

Tusekwa, A. B., Mosha, T. C., Laswai, H. S., \& Towo, E. E. (2000). Traditional alcoholic beverages of Tanzania: production, quality and changes in quality attributes during storage. Int J Food Sci Nutr, 51, 135-143.

World Health Organisation. (2014). Global Status Report on Alcohol and Health (pp. 1-43). Geneva: World Health Organization. 